DOI: https://doi.org/10.34069/AI/2021.48.12.29

How to Cite:

Kuzubov, A.A., Maksimenko, A.N., Malinina, O.Y., \& Fedorkova, A.V. (2021). Methods of improving the system of motivation of the university teaching staff. Amazonia Investiga, 10(48), 274-287. https://doi.org/10.34069/AI/2021.48.12.29

\title{
Methods of improving the system of motivation of the university teaching staff
}

\section{Методика совершенствования системы мотивации труда профессорско- преподавательского состава вуза}

Received: November 7, 2021

Abstract

The purpose of the article is a systematic scientific study of the most optimal methods for motivating personnel of higher educational institutions and their improvement, taking into account the economic state of the country and the specifics of the processes of social transformation, which formed the basis for the development of methodological and practical recommendations.

The main research methods were information retrieval methods, universal scientific methods, including methods of comparative and factor analysis, detailing, synthesis, generalization.

This publication examines the methods of motivation and incentives for the teaching staff of universities, which are in demand for use in the transition to the forms of blended and elearning, along with the use of traditional approaches; a method for calculating the fund of surcharges, allowances and other incentive payments to the teaching staff is proposed,
Accepted: December 21, 2021

Written by:

Kuzubov Alexey Alexeyevich ${ }^{120}$

https://orcid.org/0000-0001-5631-7793

SPIN-код: 3256-6820

Author ID: 823087

Maksimenko Aleskandr Nikolaevich ${ }^{121}$

https://orcid.org/0000-0003-3734-3085

SPIN-код: 6610-2592

Author ID: 833345

Malinina Olga Yurievna ${ }^{122}$

https://orcid.org/0000-0002-5352-2350

SPIN-код: 1487-7010

Author ID: 733730

Fedorkova Anna Vladimirovna ${ }^{123}$

https://orcid.org/0000-0002-7537-9241

SPIN-код: 1438-8728;

Author ID: 746330

\footnotetext{
${ }^{120}$ Candidate of Economic Sciences, associate Professor of Economics, Don State Technical University Rostov-on-Don, Russia.

${ }^{121}$ Candidate of Economic Sciences, associate Professor of Economics, Don State Technical University Rostov-on-Don, Russia

${ }^{122}$ Candidate of Economic Sciences, associate Professor of Economics, Don State Technical University Rostov-on-Don, Russia.

${ }^{123}$ Candidate of Economic Sciences, associate Professor of Economics, Don State Technical University Rostov-on-Don, Russia
} 


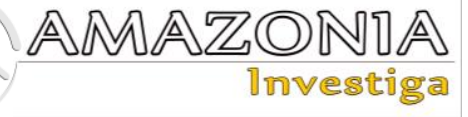

reflecting the relationship and mutual influence of workload, remuneration and surcharges, an objective assessment of work with the volume of work actually performed, overtime work, scientific work, the introduction of modern methods and technologies of teaching allows you to optimally distribute funds to motivate the teaching staff.

The materials of the article will be of interest to scientific and practical workers, graduate students and students.

Keywords: labor motivation, incentives, education, faculty, motivation factors. других выплат стимулирующего характера ППС, которая отражает взаимосвязь и взаимовлияние нагрузки, оплаты труда и доплат, объективной оценки труда с объемом фактически выполненной работы, сверхурочной нагрузки, выполнения научной работы, внедрение современных методик и технологий обучения и позволяет оптимально распределять средства на мотивацию труда ППС.

Материалы статьи будут интересны научным и практическим работникам, аспирантам и студентам.

Ключевые слова: трудовая мотивация, стимулирование, сфера образования, профессорско-преподавательский состав, факторы мотивации.

\section{Introduction}

One of the most important, generally recognized and unsolved socio-economic problems of modern Russia is the crisis of social and labor relations, which manifests itself in:

- $\quad$ underestimation of the highly qualified workforce;

- depreciation of labor values;

- loss of meaningfulness of the function of labor;

- transformation of labor from the basis of a way of life into a means of survival.

Unfortunately, this crisis is noted in many spheres and sectors of the economy, especially in universities.

The labor of university workers is one of the specific types of labor activity, which, directly or indirectly, is a necessary and obligatory component of social labor, directly related to all mechanisms of social reproduction.

Its main feature is the provision of knowledge, direct and indirect improvement of the qualifications of the labor force, that is, an increase in the efficiency of living labor.

After all, it is higher education that serves as one of the sources of the country's economic growth, making the work of each individual more productive, increasing his ability to perceive and use in practice new methods of production and management, makes it possible to manage technical means, contributes to the formation and development of scientific ideas in order to achieve the best. managing existing resources and increasing labor productivity.

The above is of particular importance in connection with the urgent need to orient the activities of the university towards achieving the results of its activities of the systemic property of emergence, which in the Higher School is considered as education, that is, an organic combination of the processes of teaching, upbringing and personal development.

Therefore, special attention of the heads of universities should be focused precisely on the effective use of personnel by stimulating a motivational orientation in their work, that is, on encouraging employees to productive activity (motivation is the main element of activating the human factor, which not only creates material prerequisites for production, but also provides them effective functioning).

The search for approaches to the improvement and formation of an effective system of labor motivation for teaching staff determines the implementation of the research and determines the relevance of the topic of work. 


\section{Theoretical Framework or Literature Review}

In general, motivation is the process of encouraging oneself and others to participate in certain activities aimed at achieving personal or organizational goals. The key link in motivation has been known for a long time and has the following form: needs-motivation-reward (Zhukovskaya, 2018).

American scientist D. Atkinson was one of the first to propose a general theory of motivation. He noted that the strength of a person's desire to achieve a set goal can be reflected by the following formula (Eren \& Yeşilburs, 2019, Dagsvik et al, 2021):

$$
\mathrm{S}=\mathrm{PP} \times \mathrm{SE} \times \mathrm{VT},
$$

$\mathrm{S}$ - the power of motivation (striving);

$\mathrm{PP}$ - the power of the motive for achieving success as a personal predisposition;

SE - subjectively estimated probability of achieving the set goal;

VT - the value of achieving this goal (task) for a person.

Any company or institution, including a university, has a major challenge to try to improve performance by motivating its employees.

Thus, we can say that each company tries to maximize the result of its activities, but each employee wants to get the result of his work in the form of a decent wage.

In practice, a result-oriented motivational model is often used, the so-called Blake-Mouton "Management grid" (Thommen et al, 2021). This is a kind of matrix formed by the cross section of two components: care for work and care for people, the analysis of the content of this model showed that:

a) satisfactory performance is maintained through the constant search for compromises between production requirements and the individual needs of workers;

b) satisfactory performance of work may be unattainable, because, on the one hand, employees are lazy, indifferent and not interested, and on the other hand, it is impossible to establish satisfactory social relations between them;

c) high labor productivity is the result of an optimal balance between production requirements and the needs of individual employees;

d) satisfaction of social needs leads employees to a relaxed friendly atmosphere of work and, accordingly, to a calm rhythm of work.

As evidenced by the results of the studies presented in the work (Ledneva \& Ivanova-Shvets, 2018), if there were sufficient means of subsistence, $20 \%$ of people would not work at all under any circumstances.

From the rest:

- $\quad 36 \%$ are ready to work if the work is interesting;

- $36 \%$ - to avoid boredom and loneliness;

- $14 \%$ - for fear of losing themselves;

- $\quad 9 \%$ - because work brings joy.

Only $12 \%$ of surveyed employees consider money to be the main motive of their activities, $45 \%$ prefer fame; $35 \%$ - satisfaction with the content of the job; $15 \%$ - the power that work gives.

Adams Scott wrote: "The reward system is an important tool for keeping income low, but the world has not yet come up with a better personnel management mechanism than methods of material incentives, methods of material reward. New approaches to incentives involve the abandonment of traditional hourly systems or pay based on the complexity coefficient, etc., as well as their replacement with wages, which consists of two components: a base rate and additional incentive payments depending on individual results and / or efficiency. divisions / companies "(Adams, 2002).

J. Adams proposed "The Theory of Justice (Equality)". According to this theory, workers subjectively determine the ratio of the remuneration received and the expended effort, and then compare it with the 
remuneration of other people for similar work. Only after receiving a fair remuneration will a person work with full dedication.

Usually, workers are dissatisfied not so much with the size of their wages as with its unfairness, the lack of its connection with the results of their labor, the chaos in the ratio of the reduction in the wages of specialists from different departments, and a sharp difference in the remuneration of homogeneous specialists at enterprises of the same region. Hence the turnover of personnel, the instability of teams, the loss of an enterprise in training new personnel, and the like (Stasyuk, 2020, Bezuglova, 2020).

Consequently, the employee motivation system should cover material and non-material remuneration in accordance with the specifics of the employee's activities. F. Herzberg proposed a two-factor model for determining motivational strength (MS):

$$
\mathrm{MS}=\left(\frac{1}{n} \sum_{i=1}^{n} H F_{i} \mid \frac{1}{m} \sum_{j=1}^{m} S F_{j}\right)
$$

where; HFi - the level of dissatisfaction with the i-th hygienic factor. One of these factors is the presence or absence of wages;

$\mathrm{SFj}$ - quantitative assessment of satisfaction of the $\mathrm{j}$-th need;

$\mathrm{n}$ - is the number of hygienic factors;

$\mathrm{m}$ - is the number of motivating factors.

The strength of the manifestation of both groups of factors (hygienic and motivating) can be assessed using a questionnaire survey of workers, where the MS fluctuates within $[-1,+1]$. The most powerful is the motivating environment with the values MS $=[0,+1]$. If the MS value is in the range $[-1,0]$, it means that there is no motivation in the organization (Westerman, 2018).

In this model, the so-called hygienic factors of behavior motivation and pure ones are distinguished.

The latter are called motivators. Therefore, the task is to find, on the one hand, factors that lead to job satisfaction, that is, are motivators, and on the other hand, hygienic factors that cause discontent and act negatively.

Motivational factors include the following:

- work-related successes;

- recognition of the employee as a person;

- the content of labor activity;

- responsibility for the assigned direction of work;

- career opportunities.

The hygienic factors of behavior motivation include:

- general principles of professional activity;

- professional leadership qualities;

- the salary;

- interpersonal relationships;

- constructive working conditions.

The conducted analytical studies allow us to conclude that the motivation and stimulation of the activities of university teachers are reduced mainly to material and monetary remuneration, and in management terms they represent the manipulation of various forms and methods of remuneration.

This relationship is focused on the form of remuneration and only secondarily on its quantitative characteristics.

Moreover, the latter are very often a kind of constants that are set by a combination of factors, including: wage rate, average wage, available resources, etc. 
The quantitative components of wages in the form-quantity dyad are less volatile than those that make up incentive controls.

Consequently, effective incentives for the teaching staff at the university can be achieved only if the following conditions are met: labor rationing and decent wages, time maneuvering and wage differentiation.

\section{Methodology}

The analysis of the current state and prospects for the development of personnel in the field of education will be presented in the form of estimated predicted values predicted of the future number of people employed in the field of education in the Russian Federation using the forecasting method based on the average growth rate of row.

In the research, the authors used official statistics on the number of people employed in the education sector in the Russian Federation.

Table 1.

The number of people employed in education in the Russian Federation.

\begin{tabular}{lllllll}
\hline Indicator & 2014 & 2015 & 2016 & 2017 & 2018 & 2019 \\
\hline Number, people & 6577 & 6667 & 6782 & 6867 & 6895 & 6840 \\
\hline
\end{tabular}

On the graph, we present the number of people employed in education at the level of the Russian Federation.

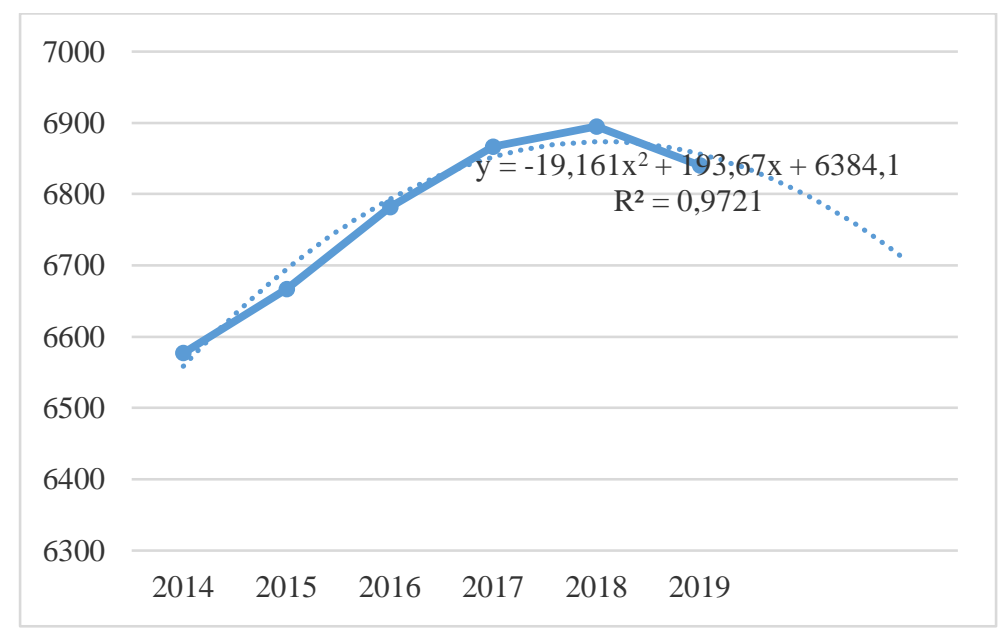

Figure. 1. Number of people employed in education at the level of the Russian Federation.

Analysis of the graph of the dynamics of the number allowed us to conclude that the time series does not have a sufficiently pronounced development trend, therefore, the forecast of the number of people employed in the field of education in the Russian Federation can be determined by the average growth rate of a row.

The average growth rate of a row is calculated by the formula:

$$
\bar{y}=\frac{\sum y_{i}}{n}
$$

$\bar{y}-$ the arithmetic mean of the series;

$y_{i}$ - the last level of the basis series;

$n$ - number of levels in the basis series. 


$$
\bar{y}=\frac{6577+6667+6782+6867+6895+6840}{6}=6771
$$

Next, you need to calculate the forecast error. Possible forecast error is calculated by the formula:

$$
\mu= \pm t \sqrt{\frac{\sigma^{2}}{n}}
$$

$t$ - normalized deviation, which is determined by the selected confidence level;

$n$ - number of known levels of the series;

$\sigma$ - the variance of the predicted market element, which can be calculated by the formula

$$
\sigma^{2}=\frac{\sum_{i=1}^{n}\left(y_{i}-\bar{y}\right)^{2}}{n}
$$

The predicted value of a market element is determined as an interval:

$$
\left\{\begin{array}{l}
\Pi_{\text {max }}=y_{p i}+\mu \\
\Pi_{\text {min }}=y_{p i}-\mu
\end{array}\right.
$$

To calculate the variance and forecast error, we will draw up a table.

Table 2.

Auxiliary calculations to determine the standard deviation.

\begin{tabular}{llll}
\hline Row levels (i) & $\begin{array}{l}\text { The actual values of the } \\
\text { levels of the row (y) }\end{array}$ & $y_{i}-\bar{y}$ & $\left(y_{i}-\bar{y}\right) 2$ \\
\hline 1 & 6577 & -194 & 37636 \\
2 & 6667 & -104 & 10816 \\
3 & 6782 & 11 & 121 \\
4 & 6867 & 96 & 9216 \\
5 & 6895 & 124 & 15376 \\
6 & 6840 & 69 & 4761 \\
Total & & & 77926 \\
\hline
\end{tabular}

$$
\sigma^{2}=\frac{779226}{6}=12987
$$

Let us determine the possible forecast error using the formula:

$$
\mu= \pm 2,58 \sqrt{\frac{12987}{6}}= \pm 2,58 \times 46,52= \pm 120
$$

Determine the confidence interval of the forecast: for 2020

$$
\begin{aligned}
& \Pi_{\text {max }}=6771+120=6891(\text { mblc.pyб. }) \\
& \Pi_{\text {min }}=6771-120=6651(\text { mblc.pyб. })
\end{aligned}
$$

The graph shows the change in the number of people employed in the field of education in the Russian Federation, taking into account the calculated forecast. 


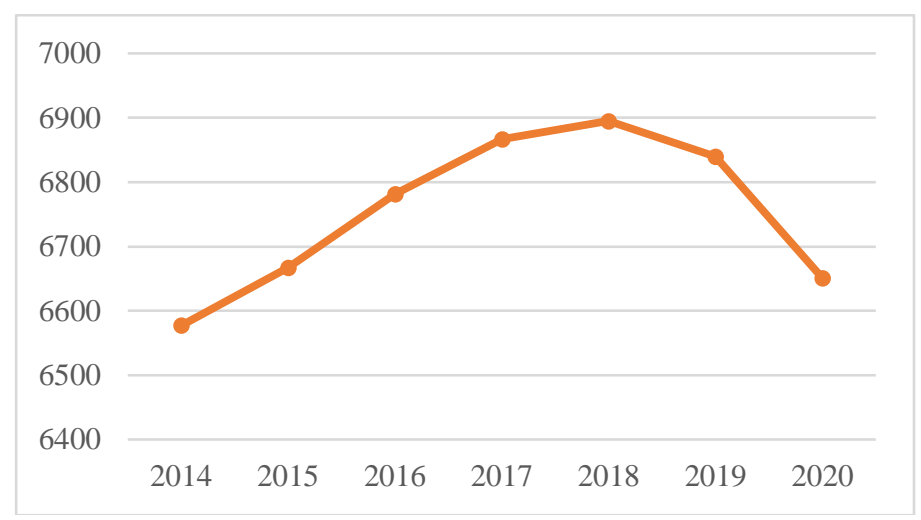

Figure. 2. Forecast of the number of employed in education in the Russian Federation

The graph shows that in the near future the number of people employed in the education sector of the Russian Federation may decrease. Then an increase in the number of people employed in the field of education is possible.

A decrease in the number of employees can lead to a decrease in overall productivity in this area. In this regard, it is necessary to improve the system of labor motivation and the calculation of the fund for allowances, additional payments and benefits.

\section{Results and Discussion}

Modern management structures of higher education institutions are complex systems, the effectiveness of which depends significantly on the quality of management.

To achieve a high quality of university management in the context of ongoing educational reforms, the leader no longer lacks personal experience, intuition and organizational skills.

This situation is due to the fact that in the formation of strategic goals and the trajectory of decision-making, the leader is forced to rely on complex evaluation criteria to achieve the final results.

Consequently, the methodological basis of the concept of university management should be not only a set of tools, methods and models for decision-making, but also modern methods of motivating the work of the teaching staff and staff (Chudnova, 2019, Denisenko et al, 2021).

The motivation for the activity of a university teacher is in many ways different from receiving payment for the provision of ordinary services.

A very important incentive for him (and this is confirmed by the data of sociological research) is the professional recognition of colleagues who are able to assess his intellectual potential and scientific competence.

This serves both as a condition for maintaining the autonomy of the teaching profession and as a means of internal control and self-regulation.

The result of the attestation of a university teacher is an academic degree and an academic title awarded by the scientific community of professionals in this specialty (Nikulina, 2008).

That is, it is impossible to achieve the set goals with people devoid of motivation.

In our opinion, the factors influencing the motivation of university staff, which should attract, stimulate people and who should exist in the atmosphere of the university, so that work in it attracts not only because of the salary, can be presented in the form of table 3 . 
It follows from this that for effective management of a university it is necessary to develop strategic management of motivation, containing a knowledge base about goals, methods of motivation and ways to achieve them.

Table 3.

Factors affecting motivation.

\begin{tabular}{|c|c|c|c|c|}
\hline People-related & Work-related & Terms of work & $\begin{array}{l}\text { Recognition and } \\
\text { encouragement }\end{array}$ & $\begin{array}{l}\text { Role and quality of } \\
\text { management }\end{array}$ \\
\hline $\begin{array}{l}\text { Family, } \\
\text { personality, } \\
\text { conditions } \\
\text { outside of work. } \\
\text { Personal interest. } \\
\text { Intellectual } \\
\text { ability. } \\
\text { Personal } \\
\text { character, } \\
\text { cultural } \\
\text { background. }\end{array}$ & $\begin{array}{l}\text { Variety of works } \\
\text { Integration, } \\
\text { integrity of } \\
\text { activities. } \\
\text { The relevance of } \\
\text { the work for the } \\
\text { organization. } \\
\text { Responsibility and } \\
\text { independence in } \\
\text { work. } \\
\text { "Feedback" on the } \\
\text { results of work. }\end{array}$ & $\begin{array}{l}\text { Physical } \\
\text { conditions. } \\
\text { Social conditions } \\
\text { (communication } \\
\text { system). } \\
\text { Cultural conditions } \\
\text { (organizational } \\
\text { culture). }\end{array}$ & $\begin{array}{l}\text { Material interest. } \\
\text { Moral interest }\end{array}$ & $\begin{array}{l}\text { Competence, } \\
\text { professionalism, } \\
\text { subsequence, } \\
\text { subsequence. } \\
\text { Commitment. } \\
\text { Honesty and fairness. } \\
\text { Definition. } \\
\text { Communicativeness. }\end{array}$ \\
\hline
\end{tabular}

Strategic management is a set of actions and procedures for the formation of strategies, their assessment and operational management of the chosen strategy.

Thus, strategic management is the main goal of development, which necessitates the solution of a number of basic interdependent tasks, which include:

- improving the management mechanism of the teaching staff;

- development of methodological foundations for organizing a labor motivation management system;

- selection of the main criteria and indicators of management efficiency in the context of education reform.

Since the objects of management are people, then, taking into account the specifics and complexity of university personnel management, it can be argued that further development and increase of motivation will take place not within the framework of one management theory, but at the junction of psychology (within the framework of studying the typology of personality behavior), sociology (in the study of public opinion and social motives), jurisprudence (within the framework of legal support of the interests of the individual), economics (within the framework of stimulating labor behavior) (Hou et al, 2021; Hitchcock et al, 2021).

In addition, the analysis carried out by the authors convincingly indicates that the development and application of modern flexible concepts of motivation is based on a rational principle of personnel behavior, which assumes that the management system should ensure mutual coordination of the interests of the individual and the individual. the university, in fact, must meet the new market requirements.

The results of the university's activities largely depend on the resources available and the efficiency of their use. In turn, effective management is determined by the attitude of personnel to work, forms and methods of motivation (Kuzubov, 2018).

As a result of the analysis of the known concepts of labor motivation in accordance with the problem under study, a generalizing interpretation of the concept of "labor motivation" is proposed, meaning the process of purposeful application of a certain set of diverse incentives to activity and regulation of labor relations to achieve the goals of the organization by coinciding its interests and the interests of the employee.

Under the conditions of a university, the organization of effective functioning is carried out on the basis of a hierarchical structure, in which information about the required level of quality of training of students is transferred from the control subsystem to the controlled one. Information about the results achieved is 
transmitted through feedback channels to the control subsystem. As a result, the interest of both subsystems in improving the quality of the educational process is ensured.

At the same time, the motivation of personnel labor is of great importance, in which two main forms can be distinguished from the point of view of scientific performance and from the point of view of scientific status. The scientific results of employees are assessed on the basis of scientific works of students, reports at conferences, monographs, etc. The scientific status is assessed in accordance with academic degrees, rank, membership in scientific societies and the position held, the creation of scientific schools, the frequency of citation in domestic and foreign publications (Voronina, 2019; Ivaniuk, 2021).

Despite the dubious validity of the assessment of personnel based on specific results, this form, without taking into account the scientific status, does not ensure the effective functioning of the university in a sufficiently long term, especially in the presence of uncertainty about the influence of the external environment (Absolon, 2019).

It follows from this that the university should be highly dynamic due to the formation of new relations, growing competition, political instability and socio-economic processes.

Moreover, as a result of the transition of the country's economy to the market, new tasks have arisen for the education system. Financial problems are particularly acute, forcing decisive action in cost adjustments and management practices.

The system of labor motivation, social guarantees and social protection is a priority in the concept of personnel policy. Reforms will not be effective without changing the wages of intellectual labor. No hiring policy can matter in hiring if it consists of unsecured income (Dagsvik, 2021; Westerman, 2018)

In this regard, it is necessary to create an effective remuneration system in universities, which would allow, firstly, to use more efficiently the already insufficient and limited budgetary funds, secondly, to optimally distribute funds between university departments, and thirdly, to attract additional sources of financing for employees' remuneration.

The authors propose the calculation of the wage fund required for the payment of benefits to teachers of higher educational institutions.

The monthly salary fund for the payment of bonuses for the position held is determined by the formula:

$$
\mathrm{MFOT}=(\mathrm{N} * \mathrm{P}) * 0.6+(\mathrm{N} * \mathrm{D}) * 0.4,(9)
$$

Where

MPF - monthly payment fund for the payment of bonuses for the position held; $\mathrm{N}$-number of staff units.

P-professors.

D-associate professors.

The amount of the allowance for an academic degree must be established by law.

- $\quad$ five times the minimum wage established by law for a doctoral degree;

- three times the minimum wage established by law for a candidate of sciences.

To pay bonuses for a scientific degree, a monthly salary fund is required:

$\mathrm{MPFAD}=5 * \mathrm{MW} *(\mathrm{~N} 1)+3 * \mathrm{MW} *(\mathrm{~N} 2), \quad(10)$

MPFAD - monthly salary fund for the payment of awards for an academic degree;

MW - minimum wage;

$\mathrm{N} 1$ is the number of full-time positions of doctors of sciences;

$\mathrm{N} 2$ - the number of staff units of candidates of sciences; 


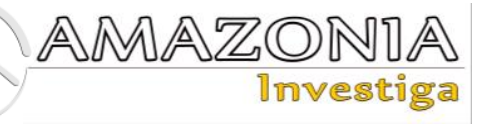

In addition to defending candidate and doctoral dissertations, stimulation of research work is proposed through lump-sum payments in the form of bonuses, or additional payments to the salary for the current year, depending on the financial capabilities of the university for such activities:

- Premium for the release of a monograph, determined by the formula: $\mathrm{PM}=\mathrm{Kc} * \mathrm{~S}$, where $(\mathrm{Kc}$ is the number of pages, $S$ is the amount of funds allocated by the university to pay for the 1st published page of the text);

- Premium for posing a significant problem, determined by the formula: PSP $=$ ES $* 3$, where (ES is the salary of one university employee);

- Premium for the introduction of a new scientific method, determined by the formula: PNM $=$ ES $* 4$, where (ES is the salary of one university employee);

- Premium for the creation of a new theory, determined by the formula: PNT $=$ ES * 10, where (ES is the salary of one university employee);

- Premium for the implementation of a new theory, determined by the formula: PINT $=\mathrm{ES} * 5$, where (ES is the salary of one university employee);

- Premium for the creation of a new scientific school, which is determined by the formula: PNSS = ES $* 8$, where (ES is the salary of one university employee);

- Premium for the training of one candidate of sciences, which is determined by the formula: PCS = ES * 7, where (ES is the salary of one university employee);

This list of premium can be supplemented depending on the specifics of the university.

Thus, the monthly salary fund of the teaching staff is:

MSFTS $=$ MFOT + MPFAD + PM + PSP + PNM + PNT + PINT + PNSS + PCS , (11)

MSFTS - monthly salary fund of teaching staff with allowances, allowances and surcharges).

In addition, the hourly wage (P) is $10 \%$ of the monthly wage fund, without additional payments to the teaching staff.

With extra-budgetary funding, the procedure for the formation and cost of the wage fund is changed. The sources for the creation of an off-budget fund can be:

- funds received for training, retraining and advanced training of specialists on a commercial basis;

- funds from the lease of fixed assets and land plots;

- proceeds from the sale of own equipment and property, educational, methodological and scientific products;

funds from the provision of additional educational and intermediary services;

funds from the provision of paid services to the population;

voluntary contributions from legal entities and individuals.

Extrabudgetary funds based on estimates can be spent on:

- development of scientific research;

- remuneration of employees;

- to establish incentive allowances, allowances and bonuses

- major and current repairs of buildings, structures and equipment;

- payment of utility and operating costs;

- material and technical support of departments;

- social payments;

- traveling expenses;

- payment of expenses for professional development of employees;

- publishing activities;

- for the payment of official salaries to the staff of departments, which are fully financed from extrabudgetary funds that are created at the university by the decision of the Academic Council;

- to pay for additional work that is not part of the direct responsibilities of an employee of this unit;

- for the remuneration of freelance employees (including students). 
Payments of this nature are made in the manner prescribed by the university.

At the University Academic Council, taking into account the financial condition of the university, the main directions of spending extra-budgetary funds from the centralized fund of the university are determined, which is approved by the order of the rector.

Within the limits of the amounts allocated for wages, based on the approved budget for the universities, the heads of departments should be involved in determining the forms and amount of remuneration for their subordinates.

In our opinion, the optimal distribution of funds for paid education in universities should be: $51 \%$ - in the funds of universities, $49 \%$ - in the funds of dean's offices. This $49 \%$ can be distributed between faculties, depending on the number of students studying on a paid basis in these dean's offices. At least a third or even a quarter of these funds can give a positive result. Delegation of functions to the heads of departments (directors of institutes, deans, heads of departments) for the management of these funds made it possible to motivate employees who ensure high-quality work of those teachers who effectively carry out their work, introduce new methods, work on candidate and doctoral dissertations, etc. which will certainly be reflected on the quality of student education and will have a positive effect on such a nationwide problem as corruption in the university.

In addition to optimizing the distribution of funds within the university, the described methodology includes a mechanism of responsibility of the heads of both the highest echelon of power of universities and structural units for the budget funding allocated to them, which distinguishes it favorably from the wellknown and promotes the promotion of universities in effective use with limited financial resources in the field of education.

The next, in our opinion, direction of increasing the motivation of the system of training university personnel should be the establishment of a relationship between the amount of remuneration and the level of implementation of modern teaching technologies, for example, distance learning systems, computerized educational systems, and so on.

Many universities are already working on the design, development and delivery of innovative training courses based on computer and telecommunication technologies, employing entire teams, "teams" of teachers of various technologists, organizers and profiles.

In traditional teaching, the teacher's contribution is calculated based on the workload of the hours that he spends on lectures, seminars, tests and exams, consultations, etc. - the number of contact hours.

How to calculate the teacher load in innovative teaching when audio, video, radio, television and electronic lectures, teleconferences and other teaching methods are actively used?

The authors analyze the characteristics of approaches to determining the contribution of teachers to traditional and innovative learning (Table 4).

Table 4.

Comparative characteristics of traditional and innovative education.

\begin{tabular}{ll}
\hline Traditional teaching & Innovative learning \\
\hline Approach to Determining Teacher Contribution & \\
Cost & According to efficiency \\
Methodology for determining the contribution of certain categories of specialists when creating training courses & Contract \\
Normative & $\begin{array}{ll}\text { Criterion for optimizing the teacher's contribution to the achievement of learning outcomes } \\
\text { (1) Increase the number of teaching hours }\end{array}$ \\
$\begin{array}{ll}\text { Increasing the number of training hours } & \text { (2) increasing the number of training hours when } \\
\text { (opening hours) } & \text { fixed cost of the course and fixed learning outcomes ("business } \\
& \text { approach") }\end{array}$ \\
\hline
\end{tabular}


1. Consider an approach to determining teacher remuneration based on teaching hours.

The key metric here is the number of hours of teaching using learning modules by those learners that the teacher has been involved in creating or using.

A training module is a relatively independent part of a training course, in which educational goals are achieved by presenting educational material based on a certain information technology (their combination) and an appropriate set of pedagogical methods and techniques.

Examples of training modules:

- watching a video lecture;

- the study of the subject and the implementation of self-control using a computer training program;

- consultations with the lecturer by e-mail;

- participation in a training video conference;

- obtaining specific statistical, experimental and other data from interactive databases;

- familiarization with the works of teachers on the pages of the World Wide Web of other educational institutions, etc.

In this case, the teacher's salary will be:

$\mathrm{T}=(\operatorname{Li} \times \mathrm{ki} \times \mathrm{ti}) \times \mathrm{h}$

$\mathrm{T}$ is the teacher's salary;

$\mathrm{Li}$ is the number of training hours based on the use of the $\mathrm{i}$-th training module $(\mathrm{i}=1, \ldots \mathrm{n})$, , created or applied with the participation of this teacher on the basis of a certain information technology (or their combination) $\mathrm{Li}=\mathrm{lij}$,

lij - is the number hours of training for the $\mathrm{j}$-th student $(\mathrm{j}=1, \ldots \mathrm{n})$ using the $\mathrm{i}$-th training module;

$\mathrm{ki}$ is the coefficient of the teacher's participation in the creation or application of the $\mathrm{i}$-th $(\mathrm{i}=1, \ldots \mathrm{n})$ training module;

ti is the coefficient of labor intensity or creation of an application for a training module based on this educational technology;

$\mathrm{h}$ - the cost of 1 hour of study at an educational institution.

The teacher maximizes the salary by increasing the number of students' teaching hours.

1. Using a "business approach" to the definition of remuneration, the teacher is looking for the fastest and most effective way to achieve the desired learning outcome for a fixed cost of the course. That is, the following statement holds: write down what you need to learn and minimize the time it takes to do this.

2. Thus, the teacher will strive for the fastest and most effective way to achieve the desired learning outcome at a fixed cost of the training course:

$\mathrm{T}=\mathrm{ki} \times(\mathrm{Si}-$ ei $\mathrm{x}$ qi) where:

$\mathrm{T}$ is the size of the teacher's salary;

ki is the coefficient of the teacher's participation in the creation or application of the i-th training module (i $=1, \ldots \mathrm{m})$, the $\mathrm{Si}-$ cost of the $\mathrm{i}$-th training module $(\mathrm{i}=1, \ldots \mathrm{m})$, is included in the cost of the training courseS $(\mathrm{S}=\mathrm{Si})$;

ei is the average hourly costs for equipment, rental of communication channels, software, administrative overheads and other costs not related to labor costs for the creation and use of the i-th training module in this educational institution;

qi is the number of training hours in the $\mathrm{i}$-th training module.

Thus, in our opinion, the procedure for assessing the teaching staff should include the following main criteria: teaching skills; scientific publications; scientific prizes and awards; introduction of new teaching methods; rating in the monthly survey of students; the degree of workload; participation in international scientific conferences; scientific work abroad; preparation of student research papers for the Olympiads; availability of graduate students; grants; patents, inventions; access to practical developments and the like. 


\section{Conclusions}

Thus, we can conclude that the development and implementation of modern teaching methods and technologies in the education system directly depends on the system of labor motivation of university employees and the amount of remuneration. Premium to the official salary of the teaching staff of universities should be established in order to ensure the most complete correspondence of salaries to the quantity and quality of their work.

The establishment of premium should be carried out for a certain period within the limits of budgetary and extrabudgetary funds.

The criteria of the teaching staff activity assessment system proposed in the article are an attempt to generalize the existing guidelines and recommendations in order to determine the criteria for measuring the level of their professional and pedagogical skills available to a wide range of people. university teachers.

The creation of an effective remuneration system in universities will allow:

- firstly, it is more rational to use funds from the university budget, in conditions of inadequacy and limitedness,

- $\quad$ secondly, it is optimal to distribute funds between the faculties of universities;

- thirdly, to attract additional sources of financing for labor remuneration.

\section{Bibliographic references}

Absolon, K. (2019). Decolonizing Education and Educators' Decolonizing. Intersectionalities: A Global Journal of Social Work Analysis, Research, Polity, and Practice, [S.1.], 7(1), p. 9-28, dec. 2019. ISSN 1925-1270. Available at: https://journals.library.mun.ca/ojs/index.php/IJ/article/view/2073

Adams, S. (2002) Top Secret Management Guide. Per. from English E. G. Handel - Minsk: OOO "Potpourri", $160 \mathrm{P}$.

Arbeláez-Campillo, D. F., Rojas-Bahamón, M. J., \& Arbeláez-Encarnación, T. F. (2018). Notes for the debate of the categories universal citizenship, human rights and globalization. Cuestiones Políticas, 34(61), 139-161.

Bezuglova, M.N. (2020) Motivation of subjects of investment in human capital. Topical issues of economics and law: problems, trends, forecasts: Collection of materials of the All-Russian scientific and practical conference. Rostov-on-Don, December 04, 2020 - Rostov-on-Don: Don State Technical University, p. 29-38.

Chudnova, O.V. (2019). Management of labor incentives for teachers of modern higher education based on the motivational model of Porter - Lawler. Sociodynamics, № 3, p. 13-17. - DOI https://doi.org/10.25136/2409-7144.2019.3.28826.

Dagsvik, J.K., Strøm, S., \& Locatelli, M. (2021) Marginal compensated effects in discrete labor supply models. Journal of Choice Modelling, 41, p. 107-125, https://doi.org/10.1016/j.jocm.2021.100326.

Denisenko, I.A., Kuzubov, A.A., \& Shashlo, N.V. (2021) The main trajectories of transformation of the labor market and labor resources in the context of digital and post-viral trends in the transformation of society. Law and management. XXI Century, T. 17, No. 3(60), p. 52-61. - DOI https://doi.org/10.24833/2073-8420-2021-3-60-52-61.

Eren, A., \& Yeşilbursa, A. (2019) Pre-service teachers' teaching-specific hopes and their motivational forces: The roles of efficacy beliefs and possible selves, Teaching and Teacher Education, 82, p. 140-152, https://doi.org/10.1016/j.tate.2019.03.016.

Hitchcock, C., Hughes, M., McPherson, 1., \& Whitaker, L. (October 2021) The Role of Education in Developing Students' Professional Resilience for Social Work Practice: A Systematic Scoping Review, The British Journal of Social Work, 51(7), Pages 2361-2380, https://doi.org/10.1093/bjsw/bcaa054

Hou, Q., Tang, X., \& Teng, M, (2021). Labor Costs and Real Sector Financing in Emerging Markets, Pacific-Basin Finance Journal, 67, p. 270-283.

Ivaniuk, H., Oleksiuk, O., \& Vyshnevetska, M. (2021). Sociocultural dominants of developing students' value intentions: context of civilization challenges. Amazonia Investiga, 10(45), 9-19. https://doi.org/10.34069/AI/2021.45.09.1

Kuzubov, A.A. (2018) Formation of the intangible component of group labor motivation. Azimuth of scientific research: economics and management, T. 7, No. 1(22), p. 147-150. 
Ledneva, S.A., \& Ivanova-Shvets, L.N. (2018) Attraction and retention of young specialists in the structure of scientific and pedagogical workers of the university. Bulletin of the Russian Economic University named after G.V. Plekhanov, No. 3 (99), p. 114-122.

Nikulina, I.V. (2008) Motivation of the professional and pedagogical activity of a higher school teacher. Bulletin of the Samara State University, No. 7 (66), 303-311.

Stasyuk, T.S. (2020) Youth in the labor market: the experience of foreign countries and Russia in ensuring the employment of young specialists. Actual problems of science and technology. Materials of the AllRussian Scientific and Practical Conference, Rostov-on-Don, March 25-27, 2020, Don State Technical University, P. 1886-1888.

Thommen, D., Sieber, V., Grob, U., \& Praetorius, A.K. (2021) Teachers' motivational profiles and their longitudinal associations with teaching quality, Learning and Instruction, 76, https://doi.org/10.1016/j.learninstruc.2021.101514.

Voronina, A.V. (2019) Features of motivation of scientific and pedagogical workers of higher education. Higher school teacher in the XXI century: materials of the International Scientific and Practical Conference, Rostov-on-Don, April 01-30, 2019 - Rostov-on-Don: Rostov State Transport University. 238-242 p.

Westerman, J. (2018) «Unequal involvement, unequal attainment? A theoretical reassessment and empirical analysis of the value of motivation in the labor market». Social Science Research, 76, pp 169-185

Westerman, J. (2018) Unequal involvement, unequal attainment? A theoretical reassessment and empirical analysis of the value of motivation in the labor market, Social Science Research, 76, pp. 169-185, https://doi.org/10.1016/j.ssresearch.2018.08.007.

Zhukovskaya, E. 2018, An integrative model for the development of motivation for innovative activities of university teachers. Problems of effective integration of the innovative potential of modern science and education: Collection of materials of the International Scientific and Practical Conference, Moscow, April 03-04, 2018 - Moscow: United edition, pp. 150-159. 